\title{
Expression of a prostaglandin D2 receptor, CRTh2 (chemoattractant receptor-homologous molecule expressed on Th2 cells) on human mast cells and potential relevance in allergic diseases
}

\author{
Tae Chul Moon*, Eduardo Campos, Tsuyoshi Yoshimura, Lisa Cameron, A Dean Befus \\ From Canadian Society of Allergy and Clinical Immunology Annual Scientific Meeting 2010 \\ Victoria, Canada. 3-6 November 2010
}

\section{Background}

Prostaglandin $\mathrm{D}_{2}\left(\mathrm{PGD}_{2}\right)$ has long been implicated in allergic diseases such as asthma by contributing to bronchoconstriction, vasodilation, and vascular permeability. Recently, cloning of a second novel $\mathrm{PGD}_{2}$ receptor CRTh2, led to a greater understanding of the physiological and pathophysiological implications of $\mathrm{PGD}_{2}$. PGD 2 signaling through DP1 and CRTh2 (DP2) mediates different and often opposite effects in many cell types of the immune system. Although mast cells (MC) are the largest source of $\mathrm{PGD}_{2}$ in the body, there is lack of information about their expression and the role of $\mathrm{PGD}_{2}$ receptors.

\section{Materials and methods}

CRTh2 transcripts and protein expression in two human mast cell lines, HMC-1 and LAD2, and two primary cultured human $\mathrm{MC}$, cord blood-derived $\mathrm{MC}(\mathrm{CBMC})$ and peripheral blood-derived $\mathrm{MC}$ (PBMC), were examined using RT-PCR and flow cytometry. Expression of CRTh2 in $\mathrm{MC}$ from human nasal polyps was examined using immunohistochemistry. Intracellular calcium mobilization after treatment with the CRTh2 specific agonist, 15R-15-methyl $\mathrm{PGD}_{2}$ was measured using Fluo-4NW calcium assay kit.

\section{Results}

RT-PCR and flow cytometry showed that human MC express CRTh2. About 35\% of tissue MC in nasal polyps

\footnotetext{
* Correspondence: tmoon@ualberta.ca

Pulmonary Research Group, Department of Medicine, University of Alberta,

Edmonton, AB, Canada, T6G 252

Full list of author information is available at the end of the article
}

expressed CRTh2. The CRTh2 specific agonist induced a dose dependent intracellular calcium mobilization in human MC.

\section{Conclusion}

Human MC express functional CRTh2. Regulation of $\mathrm{MC}$ mediator release and positive feedback recruitment of MC through CRTh2-mediated signaling may play an important role in allergic diseases.

Published: 4 November 2010

doi:10.1186/1710-1492-6-S2-P22

Cite this article as: Moon et al:: Expression of a prostaglandin D2 receptor, CRTh2 (chemoattractant receptor-homologous molecule expressed on Th2 cells) on human mast cells and potential relevance in allergic diseases. Allergy, Asthma \& Clinical Immunology 2010 6(Suppl 2):P22.

Submit your next manuscript to BioMed Central and take full advantage of:

- Convenient online submission

- Thorough peer review

- No space constraints or color figure charges

- Immediate publication on acceptance

- Inclusion in PubMed, CAS, Scopus and Google Scholar

- Research which is freely available for redistribution 